\title{
Economywide Impacts of Climate Change on Agriculture in Sub-Saharan Africa
}

\author{
Alvaro Calzadilla , Tingju Zhu, Katrin Rehdanz, Richard S. J. Tol, and Claudia Ringler
}

A pproximately 80 percent of poor people in Sub-Saharan Africa continue to depend on the agricultural sector for their livelihoods, but - unlike in other regions of the world-agriculture in Sub-Saharan Africa is characterized by very low yields due to agroecological features, poor access to services, lack of knowledge and inputs, and low levels of investment in infrastructure and irrigation. In addition, high population growth rates, especially in rural areas, intensify pressure on agricultural production and natural resources and further complicate the challenge of reducing poverty. Against this background, potential climate change poses a significant additional challenge to the future of agriculture in the region. Climate change could cause serious deterioration of rural livelihoods and increase food insecurity in Sub-Saharan Africa. Given these multiple challenges, the region's smallholders and pastoralists must adapt, in particular by adopting technologies to increase productivity and the stability and resilience of their production systems.

Improvements to agricultural productivity, often involving irrigation development, promote economic growth and provide a pathway out of poverty. Irrigation increases returns to poor households in terms of their physical, human, and social capital and enables smallholders to achieve higher yields and revenues from crop production. Irrigated farms also generate new employment opportunities through higher demand for farm labor. Poor consumers outside the agricultural sector also benefit from lower food prices because irrigation enables farmers to obtain more output per unit of input. Gains in agricultural productivity through irrigation can also stimulate national and international markets, improving economic growth. Nevertheless, rainfed farming continues to dominate agricultural production in Sub-Saharan Africa, covering around 97 percent of total cropland, which exposes agricultural production to high seasonal rainfall variability. Although irrigation systems have been promoted in the region, irrigation infrastructure has not expanded as expected mainly due to lack of demand for irrigated products, lack of access to affordable complementary inputs, poor market access, unfavorable topography, low-quality soils, and low incentives for agricultural intensification.

Despite these constraints, Sub-Saharan Africa has the potential to expand irrigation and increase agricultural productivity. A new generation of better designed irrigation projects and large, untapped water resources generate opportunities for irrigation investment in the region. In addition, with observed yields of less than one-third of the maximum attainable, the potential for productivity enhancement is significant. Finally, new investments in irrigation and improvements in agricultural productivity need complementary investments in roads, extension services, and access to markets.

This brief describes the results of a modeling exercise to forecast the economywide impacts of expanding irrigation and increasing agricultural productivity in Sub-Saharan Africa modeled under a relatively moderate SRES (Special Report on Emission Scenario) B2 climate change scenario, which was developed by the Intergovernmental Panel on Climate Change. The results were generated using a combination of economic models capable of assessing the security implications of a variety of development pathways under climate change for the period 2000-50.

\section{THE IMPACT OF CLIMATE CHANGE ON AGRICULTURAL PRODUCTION, THE ECONOMY, AND WELFARE}

The results of a scenario assuming no climate change (Scenario 1) project increased crop harvested area and crop production to the year 2050. Under this scenario, harvested area increases globally by about 3 percent between 2000 and 2050 , which is equivalent to a total area of 1.35 billion hectares in 2050, 36 percent of which would be under irrigation. In Sub-Saharan Africa, irrigated area is projected to grow more than twice as fast as rainfed area over the same period, (79 compared with 34 percent), but the share of 
irrigated area is still only 4.5 percent in 2050 compared with 3.4 percent in 2000. Total agricultural production in Sub-Saharan Africa is projected to increase by 158 percent between 2000 and 2050, whereas the share of irrigated production is projected to increase from 9 to only 14 percent over the same 50-year period.

By comparison, a scenario of moderate climate change (Scenario 2) indicates that the world's crop harvested area and food production would decrease by 0.3 and 2.7 percent, respectively, by 2050 . Under this second scenario, both irrigated area and irrigated production decrease, whereas rainfed production declines despite an increase in rainfed area. Hence, without proactive adaptation, climate change has a significant negative impact on agriculture. Both rainfed and irrigated harvested areas decrease in Sub-Saharan Africa under climate change, whereas rainfed production increases by 0.7 percent, and irrigated production drops by 15.3 percent. This sharp decrease in irrigated productivity occurs because some irrigated crops, such as wheat and sugarcane, are more susceptible to heat stress and reduced availability of water for irrigation. Under climate change, only 4.4 percent of the total crop harvested area is expected to be under irrigation by 2050 , whereas irrigated production is expected to constitute 12.1 percent of total agricultural production in the region by 2050 .

Climate change also has negative implications for gross domestic product (GDP) and child malnutrition. At the global level, GDP is expected to decrease by US $\$ 87$ billion under a scenario of moderate climate change, which is equivalent to 0.09 percent of global GDP. For Sub-Saharan Africa, GDP losses due to climate change are estimated to be US\$3.3 billion, equivalent to 0.2 percent of regional GDP. Furthermore, the number of malnourished children under five years old increases by almost 2 million in the region under this scenario.

In addition to the negative impacts described above, under a moderate climate change scenario without appropriate adaptation, the prices of agricultural commodities are projected to increase in both domestic and world markets. Real commodity prices for all cereals are projected to rise by 2050 due to increased land and water scarcity, as well as the impacts of climate change, biofuel development, increased population, and income- and growth-driven demand for food diversification. Meat prices are also expected to increase as a result of increased demand and higher animal feed prices.

\section{STRATEGIES FOR ADAPTATION TO CLIMATE CHANGE}

Adaptation by the agricultural sector can form a buffer against the negative impacts of climate change. Two different adaptation scenarios were used to evaluate the impact of adaptation on production and income. The first of these additional scenarios (Scenario 3) assumes expanded irrigated capacity, doubling the irrigated area in Sub-Saharan Africa, whereas the second of these adaptation scenarios (Scenario 4) considers productivity improvements in both rainfed and irrigated agriculture without expanded irrigated area, increasing Sub-Saharan African yields by 25 percent through investments in agricultural research and development and enhanced farm management practices.

Under Scenario 3, the expansion of irrigated area in the region from a very small base helps farmers achieve higher yields per hectare. This is followed by an increase in total crop production and a small decrease in the price of some agricultural commodities. Under this scenario, the expansion

\section{Table I The impact of climate change on agriculture in Sub-Saharan Africa}

\begin{tabular}{|c|c|c|c|}
\hline Indicator & 2000 baseline & $\begin{array}{c}\text { Scenario I: } \\
\text { no climate change, } \\
2050\end{array}$ & $\begin{array}{c}\text { Scenario } 2: \\
\text { moderate climate } \\
\text { change, } 2050\end{array}$ \\
\hline Harvested area (thousand hectares) & 181,618 & 246,363 & 244,585 \\
\hline Irrigated area (thousand hectares) & 6,243 & 11,194 & 10,801 \\
\hline Rainfed area (thousand hectares) & 175,375 & 235,169 & 233,784 \\
\hline Production (thousand metric tons) & 484,199 & $\mathrm{I}, 250,491$ & $\mathrm{I}, 23 \mathrm{I}, 158$ \\
\hline Irrigated production (thousand metric tons) & 43,398 & $|75,56|$ & $|48,70|$ \\
\hline Rainfed production (thousand metric tons) & 440,800 & $\mathrm{I}, 074,930$ & $\mathrm{I}, 082,457$ \\
\hline Share of irrigated production (\%) & 9 & 14 & 12 \\
\hline
\end{tabular}

SOURCE: IFPRI IMPACT model (2008).

NOTE: Scenario 2 is based on the Special Report on Emission Scenarios B2 scenario, developed by the Intergovernmental Panel on Climate Change. Results from the Hadley Global Circulation Model were used. 
of irrigated area in Sub-Saharan Africa increases cereal production in the region by 5 percent, and meat production by 1 percent. No change was observed for root and tuber production. Even though Sub-Saharan Africa is not a key contributor to global food production, world food prices are projected to decline under the expanded irrigation adaptation scenario, which also leads to a small increase in GDP in Sub-Saharan Africa (0.007 percent, equivalent to

US $\$ 113$ million). This slight increase, however, is insufficient to counteract the regional GDP losses expected under climate change without proactive adaptation. Results show that doubling irrigated area also reduces the number of malnourished children under the age of five years by a small amount (0.3 million children).

Adaptation also has an impact on the factors of production, such as land, labor, and capital. Market prices for labor and capital increase as the economy expands. Changes in total crop production have a mixed effect on nonagricultural sectors, but the domestic and world prices of nonagricultural products increase under this scenario. An exception is food products, for which prices decline because production is promoted by higher supply and lower crop prices.

Under Scenario 4, improvements in agricultural productivity in both rainfed and irrigated agriculture enable farmers to obtain higher levels of output per unit of input and therefore total crop production increases (although the magnitude differs by crop type). Higher levels of agricultural productivity also result in a decline in production costs and consequently a decline in market prices. A 25 percent increase in agricultural productivity leads to significant reductions in domestic and world market prices for most agricultural commodities compared with projections without proactive adaptation (that is, Scenario 2). This adaptation scenario (Scenario 4) promotes GDP growth by 1.5 percent (US $\$ 26$ billion), which more than offsets the initial reduction of 0.2 percent in GDP due to climate change as projected

\section{Table 2 The impact of climate change and adaptation in Sub-Saharan Africa, 2050}

\begin{tabular}{|c|c|c|c|c|}
\hline Indicator & $\begin{array}{l}\text { Scenario I: } \\
\text { no climate } \\
\text { change, } \\
2050\end{array}$ & $\begin{array}{l}\text { Scenario 2: } \\
\text { moderate } \\
\text { climate } \\
\text { change, 2050 } \\
\text { (without }^{\text {adaptation) }}\end{array}$ & $\begin{array}{c}\text { Scenario 3: } \\
\text { moderate } \\
\text { climate } \\
\text { change, 2050, } \\
\text { with a } \\
\text { doubling of } \\
\text { irrigated } \\
\text { area }^{b}\end{array}$ & $\begin{array}{c}\text { Scenario 4: } \\
\text { moderate } \\
\text { climate } \\
\text { change, } 2050, \\
\text { with a } 25 \% \\
\text { increase } \\
\text { in irrigated } \\
\text { and rainfed } \\
\text { crop yields }\end{array}$ \\
\hline Total production (thousand metric tons) & $1,250,491$ & $-1.5 \%$ & $0.1 \%$ & $18.0 \%$ \\
\hline Rainfed production (thousand metric tons) & $1,074,930$ & $0.7 \%$ & $-0.6 \%$ & $17.9 \%$ \\
\hline Irrigated production (thousand metric tons) & $|75,56|$ & $-15.3 \%$ & $99.5 \%$ & $23.4 \%$ \\
\hline Total area (thousand hectares) & 246,363 & $-0.7 \%$ & $0.0 \%$ & $0.0 \%$ \\
\hline Rainfed area (thousand hectares) & 235,169 & $-0.6 \%$ & $-4.8 \%$ & $0.0 \%$ \\
\hline Irrigated area (thousand hectares) & 11,194 & $-3.5 \%$ & $100.0 \%$ & $0.0 \%$ \\
\hline Change in welfare (US\$ millions) & -- & ।,786 & 119 & 15,435 \\
\hline \multicolumn{5}{|l|}{ Change in GDP } \\
\hline US\$ millions & -- & $-3,333$ & 113 & 25,720 \\
\hline Percentage & -- & $-0.2 \%$ & $0.0 \%$ & $1.5 \%$ \\
\hline Malnutrition (million children under age five) & 30.2 & 32.0 & 31.7 & 30.4 \\
\hline
\end{tabular}

SOURCE: IFPRI IMPACT and GTAP-W results (2008).

NOTE: Scenarios 2, 3, and 4 are based on the Special Report on Emission Scenarios B2 scenario, developed by the Intergovernmental Panel on Climate Change. Results from the Hadley Global Circulation Model were used.

a Indicates the percentage change with respect to Scenario I.

$\mathrm{b}$ Indicates the percentage change with respect to Scenario 2. 
under Scenario 2. Increased rainfed and irrigated crop productivity also significantly reduces the number of malnourished children (by 1.6 million children), essentially canceling out the increases in malnutrition caused by climate change.

In addition, market prices for rainfed land, irrigated land, and irrigation decline, while market prices for all other primary factors increase. The increase in the market price for unskilled labor is higher than for skilled labor under the second adaptation scenario (Scenario 4). Total production in nonagricultural sectors is also affected under Scenario 4. Reductions in total production are more pronounced for energy-intensive industry, other industry and services, and gas. Food products are positively affected, with production increasing by 1.4 percent. Domestic and world market prices increase for all nonagricultural sectors except for the food product industry.

\section{IMPLICATIONS}

Given the relatively low share of irrigated area in Sub-Saharan Africa, an increase in agricultural productivity achieves much larger benefits for the region than doubling irrigated area alone. The results show that improving crop yields in both rainfed and irrigated areas is a strategy that could almost completely offset the negative impact of climate change on productivity, GDP, prices, and child malnutrition. Substantial productivity gains are technically feasible in Sub-Saharan Africa because agricultural productivity is far below its potential.

An increase in agricultural productivity widely exceeds the GDP losses due to climate change, whereas increasing irrigated area alone does not offset GDP losses due to climate change. While these results are promising in terms of the potential to develop investment programs to counteract the adverse impacts of climate change, the climate change scenario implemented here is conservative in light of the range of potential climate change scenarios that could ultimately eventuate.

\section{FOR FURTHER READING}

Calzadilla, A., T. Zhu, K. Redhanz, R. S. J. Tol, and C. Ringler, Economywide Impacts of Climate Change in Sub-Saharan Africa, IFPRI Discussion Paper No. 873 (Washington, DC: International Food Policy Research Institute, 2009).

\begin{abstract}
Alvaro Calzadilla (alvaro.calzadilla@zmaw.de) is a PhD student at the Unit Sustainability and Global Change, Hamburg University, and the Centre for Marine and Atmospheric Science, Hamburg, Germany. Tingju Zhu (t.zhu@cgiar.org) is a senior scientist in the Environment and Production Technology Division of the International Food Policy Research Institute (IFPRI), Washington, D.C. Katrin Rehdanz (katrin.rehdanz@ifw-kiel.de) is an assistant professor in the Department of Economics at Christian-Albrechts-University, Germany. Richard S. J. Tol (richard.tol@esri.ie) is a research professor at the Economic and Social Research Institute, Dublin, Ireland. Claudia Ringler (c.ringler@cgiar.org) is a senior research fellow in IFPRI's Environment and Production Technology Division.
\end{abstract}

This series of IFPRI Research Briefs is based on research supported by the Federal Ministry for Economic Cooperation and Development, Germany, under the project "Food and Water Security under Global Change: Developing Adaptive Capacity with a Focus on Rural Africa," which forms part of the CGIAR Challenge Program on Water and Food. Through collaboration with the Center for Environmental Economics and Policy in Africa, the Ethiopian Development Research Institute, the Ethiopian Economics Association, and the University of Hamburg, the project aims to provide policymakers and stakeholders in Ethiopia and South Africa with tools to better understand and analyze the consequences of global change-in particular climate change—and to form policy decisions that facilitate adaptation in these countries and beyond.

\title{
Financial Contributors and Partners
}

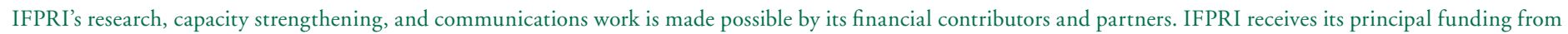

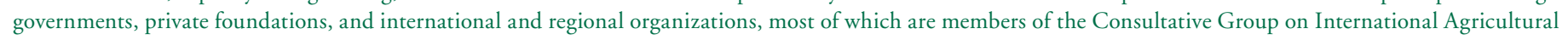

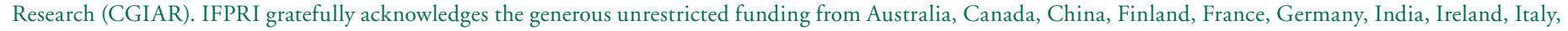
Japan, Netherlands, Norway, South Africa, Sweden, Switzerland, United Kingdom, United States, and World Bank.

Printed on alternative-fiber paper manufactured from agriculturally sustainable resources that are processed chlorine-free (PCF).

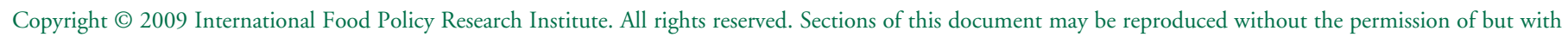
acknowledgment to IFPRI. Contact ifpri-copyright@cgiar.org for permission to reprint. 